\title{
ELECTORAL GOVERNANCE AND DEMOCRATISATION IN SOUTHERN AFRICAN POST-CONFLICT STATES \\ Electoral Management Bodies in Angola, Mozambique and South Africa
}

\begin{abstract}
Albano Agostinho Troco
Albano Agostinho Troco is NRF/British Academy Post-doctoral Research Fellow in the Department of Political Studies, University of the Witwatersrand
\end{abstract}

\begin{abstract}
Democratisation is a complex process that includes crafting political institutions. These institutions reflect existing power relations at the critical juncture of their genesis, thus influencing the development of subsequent political processes. The study uses this perspective to examine the impact of electoral governance on democratisation with a focus on three southern African post-conflict states. Specifically, the paper investigates the role of electoral management bodies (EMBs) in accounting for the distinctive regime trajectories in Angola, South Africa and Mozambique. The analysis suggests that successful attempts by incumbents to redesign EMBs after the founding elections have led to the establishment of self-serving institutions of electoral governance. This has had a negative impact on the credibility of subsequent electoral processes and the nature of the emerging regimes in the countries under scrutiny.
\end{abstract}

Keywords: electoral governance, electoral management bodies, democratisation, southern Africa, post-conflict states

\section{INTRODUCTION}

Although some southern African countries have held multiparty elections since the 1960s, the vast majority of states in the region have a more recent history with multiparty elections. This history, which can be traced back to the arrival of the 'third wave' of democratisation in the region in the early 1990s, has seen many African countries holding their first multiparty elections after decades of 
white minority rule, one-party states and civil wars. ${ }^{1}$ At present, the political landscape of the Southern African Development Community (SADC) region includes a variety of regimes: closed authoritarian regimes (Swaziland); electoral authoritarian regimes (Angola, the Democratic Republic of Congo, Madagascar, Zimbabwe), electoral democratic regimes (Lesotho, Malawi, Mozambique, Tanzania), and liberal democratic regimes (Botswana, Mauritius, Namibia, Seychelles, South Africa) (Matlosa 2017, p. 13). ${ }^{2}$

In Namibia, Angola, Mozambique and South Africa, democratisation emerged in the context of political negotiations to settle protracted armed conflicts. The resulting peace settlements and transition pacts provided for inclusive multiparty elections as a tool to conclude the move to a new democratic order. A quarter of a century later, these countries occupy distinctive positions in various regime indexes, ranging from electoral authoritarian regimes (Angola), electoral democratic regimes (Mozambique) and liberal democratic regimes (Namibia and South Africa). What explains the variation in the democratic trajectories of these states?

This article sets out to answer the aforementioned question with a focus on electoral governance. More specifically, the study investigates the impact of electoral management bodies (EMBs) on the nature of democratisation processes observed in Angola, Mozambique and South Africa. In addition to a common geographical location and a history of protracted conflict, these three countries held their founding elections at around the same time, they use variations of the same electoral system (closed-list proportional representation), have adopted regulative frameworks that provide for independent EMBs, and their first elections confirmed the strength of national liberation movements that have been in power ever since. ${ }^{3}$

The article is based on textual analysis of secondary qualitative data sources such as books, peer-reviewed articles, legislation and reports. It is informed by the view that although democracy is not limited to elections, its minimum requirement is free and fair elections, as 'the idea of democratic self-government is incompatible with electoral farces' (Schedler 2002, p. 37). From this perspective, the success of democratic transition and consolidation processes presupposes the

1 The exception is Swaziland which has banned political parties and remains an absolute monarchy.

2 This classification is in agreement with the Freedom House Index 2018 ratings for the countries in question. The Freedom House Index is an annual freedom barometer that measures the levels of civil and political freedom in the world placing in three different categories: Free, Partly and Not Free, which are proxies for democratic, hybrid and authoritarian regimes, respectively.

3 Namibia has been excluded from the analysis because the country's transition is considered to be a case of decolonisation from a foreign occupying force. The withdrawal of the South African military in the months leading up to the founding elections removed the issue of power and cohabitation between the main belligerents in the post-conflict era. 
organisation and administration of free and fair electoral processes. Electoral governance plays a crucial role in the accomplishment of this goal, thus placing EMBs at the centre of democratisation processes.

The discussion opens with an exploration of the concept of electoral governance and the major assumptions of historical institutionalism, which provide the theoretical foundations of the work. This is followed by an in-depth analysis of the pattern of electoral governance in Angola, South Africa and Mozambique. The final section summarises the central argument advanced in the study, noting that institutions of electoral governance matter in accounting for democratisation.

\section{ANALYTICAL FRAMEWORK: ELECTORAL GOVERNANCE AND HISTORICAL INSTITUTIONALISM}

Identified as the 'omitted variable' in explaining both the success and failure of democratic transitions, there are no doubts today that electoral governance plays a central role in ensuring the credibility of electoral processes in emerging democracies (Pastor 1999, p.15). Electoral governance is defined as the wider set of activities that creates and maintains the broad institutional framework in which voting and electoral competition take place' (Mozaffar \& Schedler 2002, p. 7). It operates on the three levels of 'rule making, rule application, and rule adjudication' (ibid.). Put differently, electoral governance involves the design and implementation of electoral rules as well as the resolution of disputes that emerge in the course of the electoral game. These tasks are often carried out by EMBs as these entities represent the institutional embodiment of electoral governance.

Broadly speaking, an EMB is an institution responsible for organising and administering elections. ${ }^{4}$ The primary categorisation of EMBs focuses on the place of these institutions within the structure of the state. In this regard, three broad models of electoral management have been identified, namely: independent, governmental and mixed models. Under the independent model, elections are managed by an autonomous entity that is independent from the executive. Under the government model, elections are conducted entirely by governmental authorities through a ministry or other state-controlled entity. Under mixed models, the government manages the elections with the oversight of an independent supervisory body. However, irrespective of the model, EMBs are expected to discharge their duties with independence, impartiality, integrity,

4 A variety of labels have been used to refer to these institutions including Election Commission, Department of Elections, Electoral Council, Election Unit or Electoral Board. The term EMB is commonly used to reflect this terminological diversity. 
transparency, efficiency, professionalism and service mindedness so as to ensure democratic credibility (Catt, Ellis, Malley, Wall \& Wolf 2014, p. 21).

In the old and established democracies of north America and western Europe the administration of elections follows the governmental model; however, the general trend in third wave democracies has been the establishment of independent EMBs (Lopez-Pintor 2000, p. 20). In this regard, Pastor (1999) reports that 'the progress toward democratization in the developing world has coincided with a tendency toward placing increasing responsibility for conducting the elections in independent commissions' (p. 14). The removal of electoral management from executive control in new democracies has been devised to prevent incumbents from manipulating elections. It is believed that the establishment of an autonomous EMB helps to insulate electoral governance from the incumbent in particular and politics in general.

Several studies have confirmed these assumptions. For instance, Hartlyn, McCoy \& Mustillo (2008) found that 'professional and independent EMBs free from partisan influence and government control provide a much greater chance of successful elections, particularly relative to those dominated by a single party' (p. 92). Similarly, Gazibo (2006) writes that 'a correlation exists between the process of forging EMCs [EMBs], their level of autonomy and the course of democratization' (p. 690). These claims are in line with a broader argument in Africanist literature highlighting the fact that 'variations in the quality of democracy are shaped by the strength and independence of political institutions' (Cheeseman, Collord \& Reyntjens 2018, p. 38).

In this study, the status of the EMB is determined by examining both formal rules and actual practices. In other words, the assessment of the independent or non-independent character of an EMB and its impacts on political outcomes in the countries under scrutiny focusses not only on the institutional configuration outlined in legal documents, such as a constitution and specific legislation, but also on how electoral governance is effected through these institutions. The analysis also incorporates insights from the historical institutionalist school of thought regarding how institutions emerge and are transformed.

From a political science perspective, historical institutionalists believe that 'political analysis is best conducted through a focus on institutions or, more specifically, when starting off with institutions' (Lecours 2005, p.6). Historical institutionalists tend to work with a broad definition of political institutions described as 'not just formal rules, procedures or norms, but the symbol systems, cognitive scripts, and moral templates that provide the "frames of meaning" guiding human action' (Taylor 1996, cited in Lowndes \& Roberts 2013, p. 38). Political institutions are assumed to be instruments that frame the actions of political actors and arenas where decisive struggles over values are fought as 
they distribute power amongst contending groups in society (Lowndes \& Roberts 2013, p. 77).

In this context, the prevailing power relationship between political actors is a crucial variable in the genesis of institutions, as strategic political actors seek to make their values last through institutional design (Mozaffar \& Schedler 2002 , p. 14). This means that the correlation of power between the incumbent and opposition parties tends to shape the character and actions of EMBs. Consequently, historical institutionalists take history seriously. This is mainly because political events take place within a historical context, which influences subsequent decisions or events.

Historical institutionalists adopt a perspective on historical development that emphasises path dependence. The concept of path dependence 'involves the idea that once a country or a region has started down a track, the costs of reversal are very high. There will be other choice points, but the entrenchments of certain institutional arrangements obstruct an easy reversal of the initial choice' (Lecours 2005, p. 9). It is grounded on a conception of positive feedback, which creates a powerful cycle of self-reinforcing rules and practices. This has led to criticisms about historical institutionalism, like its rational choice and sociological counterparts, having a bias towards order and stability. However, in general, historical institutionalists explain institutional development with reference to the notions of punctuated equilibrium and critical junctures. These are crucial founding moments at which new institutions are born and new patterns of path dependence begins.

Lastly, historical institutionalism does not claim that institutions are the only variable in politics. As highlighted by Hall \& Taylor (1996), 'historical institutionalists seek to locate institutions in a causal chain that accommodates a role for other factors, notably socioeconomic development and the diffusion of ideas' (p. 942). In this respect, the authors conclude, 'they [historical institutionalists] posit a world that is more complex than the world of tastes and institutions'. This is to acknowledge the fact that EMBs are one of the many contextual variables affecting the course of democratisation in the countries under examination and constitute the analytical focus of this inquiry.

\section{A PARTISAN EMB IN POST-WAR ANGOLA}

Angola attained independent statehood during a raging war. The armed conflict started in 1961 as a war of national liberation against Portuguese colonial rule, and developed through different stages of intensity and character until it ended in 2002. Between 1975 and 1991 the conflict became entangled in the dynamics of the Cold War in southern Africa, opposing the MPLA and UNITA and their 
respective external backers. The New York Agreements in December 1988 provided for the withdrawal of Cuban troops from Angola and South Africa's commitment to grant independence to Namibia; though this settled the regional dimension of the conflict, it left the domestic dimension unresolved. The civil war raged on until it was eventually settled at the negotiation table when the ruling MPLA and UNITA forces signed a peace agreement in Lisbon on 31 May 1991.

The peace agreement, commonly referred to as the Bicesse Accords, focussed on military and political aspects. On the military front, the agreements called for a ceasefire, the disbandment of the existing armed forces and the creation of a new unified army. On the political front, it called for democratisation, providing for presidential and legislative elections to be held between September and November 1992. Monitoring the implementation of the agreements was assigned to a Joint Political-Military Commission and international observers represented by Portugal, the Soviet Union, the United States (US) and the United Nations (UN). Subsequently, a series of legislative and administrative reforms was set in motion in preparation for the first multiparty elections, since at the time Angola had experience with only a single-party system. There was an understanding that the final institutional framework of a representative democratic state, including a constitution, would be the prerogative of an elected parliament.

The Electoral Act, which was approved on 16 April 1992 (Law 5/92), defined the Conselho Nacional Eleitoral (National Electoral Council or CNE) as an entity with the broad mandate to coordinate and execute all activities related to the electoral process (arts.12-13). The CNE was to include an executive body (comprising the commissioners) and an administrative structure comprising the General Direction of Elections, Provincial Electoral Councils and Municipal Electoral Offices. These structures were to be led by National, Provincial and Municipal Electoral Directors respectively (art.15-18). The composition of the CNE included a wide range of actors appointed according to different criteria: a judge of the Supreme Court (elected by the plenary of the court); a judicial magistrate (appointed by the president of the Supreme Court); five individuals (appointed by the head of state); the Minister of Territorial Administration (Home Affairs); a National Director of Elections (appointed by the head of state after consulting with the leadership of competing political parties); a representative from the Media Regulatory Body; and a representative from each of the parties running in the elections. Presidential candidates were also entitled to appoint members to the commission (art.14). The same logic of appointment was followed at the provincial and local structures of the EMB.

The CNE began its operations in early May 1992. Although neither the existing constitutional law nor the electoral act made explicit reference to the independent character of the CNE, the credibility of the commission remained 
high throughout the electoral process. This was mainly due to UN support, a strong international monitoring presence and the balanced composition of the CNE. Consequently, when elections were held on 5 and 6 September 1992, they 'were unmarred by serious incident, and proceeded in a manner that all international observers declared free and fair' (Tvedten 1993, p.108). Nonetheless, Angola's founding elections proved unsuccessful as UNITA rejected the electoral verdict, plunging the country back into civil war.

The armed conflict raged on for another decade until it was brought to an end with the military defeat of UNITA in 2002. The victor status of the MPLA government and the absence of meaningful internal opponents (civil or military) imbued the ruling party with enough latitude to deploy strategies to ensure the preservation of the party's status as 'Angola's hegemonic political force' (Soares de Oliveira 2015, p. 91).

The approval of the legal framework, including the establishment of the new EMB for the first post-war elections in September 2008, illustrates one such strategy. The new Electoral Law (Law 06/05) changed the name of the EMB from National Electoral Council to Comissão Nacional Eleitoral (National Election Commission, or CNE). It defined the CNE as 'an independent, participatory body that shall coordinate the execution, conduct and realization of all the activities and operations regarding the elections, as well as to oversee the voter registration process' (art.154). Like the previous EMB, the administrative structure of the new CNE encompassed Provincial Electoral Commissions (CPE), Municipal Electoral Offices (GME) and District Electoral Offices (GCE) (art. 157). The CNE was to be composed of eleven members selected as follows: two commissioners appointed by the president of the Republic; six commissioners appointed by the National Assembly (three nominated by the majority party, two by the largest opposition party, and one by the second-largest opposition party); a judge appointed by the Supreme Council of the judiciary, one commissioner appointed by the Conselho Nacional da Comunicação Social (National Council for the Media - CNCS) and one by the Ministry of Home Affairs or MAT (art. 156). The same logic of selection was replicated at the sub-national structures of the CNE.

Despite being defined as an independent body, the autonomy of the CNE was limited to legal provisions regarding its institutional configuration. In other words, the CNE was independent in the sense that it was not administratively under the jurisdiction of a ministry or a government department. In practice, however, the selection procedure for commissioners as well as the mandate and modus operandi of the commission undermined the impartiality expected from an EMB. For instance, the procedure for selecting commissioners gave the MPLA direct influence on the appointment of two-thirds of commissioners. This was in consideration of the fact that President dos Santos, who was both head of state 
and president of the ruling MPLA, had the constitutional mandate to appoint Supreme Court judges, while the CNSC and the MAT were in essence MPLAdominated institutions.

The MPLA emerged as the winner of the 2008 electoral process with an overwhelming majority of $81.6 \%$ of the votes. This outstanding electoral result meant that the party now controlled 191 seats in the 220-seat National Assembly (parliament), a supermajority that imbued the MPLA with enough power to govern and to go ahead with the implementation of any structural political reform unchallenged. Subsequently, President Dos Santos and the MPLA went on to consolidate their hegemonic control over the Angolan political system through the constitution-making process: the MPLA by pre-empting the possibility of losing power through elections and the president by cementing his personal power and position as the dominant figure in Angolan politics (see Troco 2019, pp. 32-36).

The approval of the Constitution of the Republic of Angola (CRA) in February 2010 occasioned the revision of most sub-constitutional legislation to conform to the new constitutional order. In this context, the new constitution reaffirmed the status of the CNE as 'an independent administrative body' (art. 107, CRA 2010). However, the actual independence of the commission remained questionable because the legal provisions for the appointment of its members turned the EMB into a partisan entity dominated by the ruling party. The number of commissioners expanded from 11 to 17 . These include the president (a judge appointed by the Supreme Council of the judiciary) and 16 commissioners nominated by political parties and party coalitions according to their seats in parliament. After being nominated by their parties, commissioners are officially appointed in the National Assembly by an absolute majority of votes (art.143, Law 36/2011). According to the law, the outcome of the elections determines the number of commissioners a party is entitled to nominate. Thus, the outcome of the 2008 elections resulted in the following allocation for the 2012 elections: nine commissioners for the MPLA, three for UNITA, two for the PRS, and one each for the FNLA and ND-UE respectively (art.209, Law 36/2011). ${ }^{5}$ The fact that the same logic is followed in the appointment of commissioners at the provincial, municipal and local structures of the CNE ensures the MPLA's hegemonic control over the commission.

The partisan character of the CNE has turned the commission into a miniature replica of the National Assembly in which the ruling party dominates with the required majority to approve or block any decision it deems fit for its political agenda. This is particularly challenging since the Angolan electoral commission doubles as an electoral tribunal, working as a court of first instance in

5 The outcome of the 2012 electoral process ensured that the MPLA was entitled to appoint the same number of commissioners in the 2017 electoral process. 
the settlement of electoral disputes. The decisions of the CNE can only be appealed at the Constitutional Court. However, the court is perceived to be biased, partly because the head of state and the MPLA dominate the process of appointing judges. Accordingly, the Constitutional Court is composed of 11 judges appointed as follows: four judges appointed by the president of the Republic, including the president of the court; four judges appointed by the National Assembly by an absolute majority of votes, including the deputy-president of the court; two judges appointed by the Supreme Council of the judiciary; and one judge selected by a process of public competition among legal professionals (art.1, Law 24/10).

As a result, the electoral commission has been at the centre of major electionrelated controversies in the country. For instance, in the months leading up to the 2012 elections, the head of the CNE, a high-ranking MPLA official, was forced to resign after the Supreme Court found her re-appointment to the position to be unlawful. However, successive attempts by opposition parties to invalidate the decisions made by the official during her contentious tenure (roughly three months before polling day) were unsuccessful. The MPLA won those elections with 71.8\%, which correspond to 175 out of 220 seats in parliament. More recently, during the 2017 electoral process, opposition parties accused the CNE of hiring INDRA and SINFIC without following proper procedure. The process leading to the selection of these two companies was shrouded in mystery, suggesting previous agreement between the commission and the companies. The events took place in a context whereby the two companies did not enjoy any trust from opposition parties as they stood accused of helping to rig previous elections. Nonetheless, the CNE's controversial decision prevailed and the two companies continued to supply the electoral logistics and computer programs for the elections. In this instance, the MPLA gained $61.1 \%$ of the votes giving the party 150 out of 220 seats in the National Assembly (Troco 2019, pp. 29-30).

The point here is to show that an institutionally weak democratic framework enables weak electoral governance with deleterious effects on the overall political system, as argued by the author in a previous study (Troco 2019, p. 32). In this regard, the case of Angola and Mozambique (to be examined later) illustrates how, in emerging democracies, the ruling party can use its dominant position to entrench a biased election management system based on a principle of parliamentary representation. This defies the basic principles of equality and fairness, ${ }^{6}$ as, ideally, multiparty EMBs should reflect the breadth of political contestants on an equal basis, not the electoral strength of the contesting parties.

6 An election is free when voters can choose candidates, political parties and policies without any form of undue influence, coercion or intimidation; and fair when contenders are treated equally, and the electoral contest takes place on a level playing field, that is when everyone has the same chance of succeeding (Troco 2019, p. 26). 


\section{AN INDEPENDENT EMB IN POST-APARTHEID SOUTH AFRICA}

In South Africa, the impossibility of either the National Party (NP) or the African National Congress (ANC) prevailing over the other encouraged the two parties to seek an end to the apartheid system through a negotiated settlement. Formal negotiations to move the country to an inclusive, multiracial democratic order started in earnest with the Convention for a Democratic South Africa (CODESA) in December 1991. These initial negotiations collapsed in mid-1992 as the parties could not reach a consensus on the shape and form of the interim government and the constitution.

Subsequently, the NP and the ANC proceeded with bilateral negotiations, reaching an agreement on a joint negotiating position by the end 1992. The two parties agreed to convene a new multi-party forum to draft an interim constitution and a bill of rights stipulating non-negotiable constitutional principles to be enshrined in the final constitution; to hold non-racial elections to choose delegates for the Assembly that would write the final constitution, and political parties to serve in the transitional government of national unity; and to set up a transitional government for a five-year period during which the final constitution would be drafted (Gilliomee 1995, p. 97). This was, in essence, a power-sharing agreement designed to serve as a blueprint for future negotiations on South Africa's transition to an inclusive democratic order.

Another round of formal negotiations opened under the framework of the Multiparty Negotiating Process (MPNP). The gathering started on 1 April 1993 with delegates from 26 organisations, including political parties, national and homeland government representatives and traditional leaders. By July 1993, the MPNP Negotiating Council had endorsed the roadmap laid out by the NP and the ANC announcing the date of the inaugural non-racial elections as 27 April 1994. These developments galvanised discussions towards drafting legislation to set up the various institutions that would oversee the period of transition prior to polling day. The aim was 'to create an "even playing field", which negotiators thought would be impossible if the transitional process was left to the National Party-controlled government to steer' (Ndletyana 2015a, p. 26).

Consequently, a comprehensive package of transitional legislation-including the Interim Constitution (Act No. 200 of 1993), the Electoral Act (Act No. 202 of 1993) and the Independent Electoral Commission Act (No. 150 of 1993) - was approved, providing the legal foundation for the establishment of critical transitional governing institutions. Several institutions were set up, including a Transitional Executive Council (TEC) - mandated to share executive authority with the NPled government; an Independent Media Commission (IMC) - created to ensure 
fair and even coverage of the electoral process; and an Independent Electoral Commission (IEC) - tasked to manage and administer free and fair elections.

The IEC, which was inaugurated in December mid-1993, followed the independent model. The autonomy of the IEC was expressed primarily in terms of its institutional configuration, as it was structurally separated from the executive. This institutional arrangement contrasted with the practices of the apartheid era where the Department of Home Affairs administered elections, resulting in almost absolute executive control over the conduct of elections and electoral outcomes. The IEC's independence was reaffirmed in the procedure for selecting commissioners. In this regard, the IEC Act empowered the president of the Republic, upon consulting the TEC, to appoint not more than eleven South African commissioners and five international commissioners. The IEC also enjoyed financial autonomy, as the Commission was entitled to draw up its own budget (to be paid by Parliament) and expected to account for its expenditures to the Auditor-General.

Furthermore, there were systems of checks and balances guiding both the structure and workings of the IEC. The Commission was structured as a three-bodied institution - the Election Administration Directorate, the Election Monitoring Directorate and the Adjudication Secretariat - headed by commissioners who were the executive authority of the IEC. The Administration Directorate was responsible for logistics and administrative tasks like the registration of parties and education of voters. The Monitoring Directorate was mandated to monitor the different steps of the electoral process both within and outside the Commission so as to ensure a fair process. The Adjudication Secretariat was responsible for settling electoral disputes and included a Special Electoral Tribunal, Election Appeals Tribunal and Special Electoral Courts.

Despite some administrative irregularities, South Africa's founding elections were deemed to be a success as all contending parties accepted the electoral outcome. The event signalled the beginning of a new democratic order, which came to fruition with the inauguration of the Government of National Unity. Part of this success story can be attributed to the structure and non-partisan character of the IEC. As reported by Mawson (2010b, p. 2): 'although the ultimate success of the elections can largely be attributed to the political will of the participants to see the elections through successfully, the electoral commission nurtured and sustained this political will'.

The IEC was an interim body mandated to run the first non-racial elections and was consequently disbanded in late 1994. Deliberations for the creation of a permanent EMB began with the newly elected parliament. Appropriate legislation, including the final Constitution of the Republic of South Africa (Act 108 of 1996) and the Electoral Commission Act (Act 51 of 1996), was approved in October 1996. 
The new legislative framework incorporated most of the provisions of the interim IEC, while introducing changes in relation to the functions, size, composition and structure of the commission.

Chapter 9 of the Constitution defines the new EMB as the Electoral Commission, placing it in the list of state institutions designed to strengthen constitutional democracy in the Republic of South Africa. Its functions, defined in section 190, include managing the elections of national, provincial and municipal legislative bodies; ensuring that elections are free and fair; and announcing electoral results. Like its interim predecessor, this body follows the independent model of electoral management being subject only to the Constitution and the Law (Chapter 2, sections 3). The IEC also enjoys budgetary autonomy, accounting to the Auditor General for the expenditure of public funds.

As a permanent body, however, the powers, duties and functions of the IEC increased, ranging from the management of elections, the compilation and maintenance of voters' roll and voter education, to the adjudication of electoral disputes (Chapter 2, section 5). The size of the Commission decreased from 16 to five commissioners (with the provision that one of them be a judge). Commissioners were to be appointed by the president of the Republic on the recommendation of the National Assembly from a list of candidates submitted by an independent panel consisting of the president of the Constitutional Court, a representative of the Human Rights Commission, a representative of the Commission on Gender Equality, and the Public Protector (Chapter 2, sections 6-7). Candidates are expected to have left high party/political positions by the time of their appointment and commissioners are barred from appointment to any political office for a period of 18 months after the end of their term in office. These conditions were introduced to reinforce the independence of the Commission.

Change was also observed in the structure of the Commission, comprising an executive authority, an administrative office and the Electoral Court. The commissioners had executive powers, which included appointing the chief electoral officer (CEO). The chief electoral officer heads the administration of the Commission, which has offices and staff at the national, provincial and municipal levels. The Electoral Court (sections 18-20) has the status of a Supreme Court and is empowered to review any decision of the Commission relating to an electoral matter. Furthermore, the court has the prerogative to investigate any allegation of misconduct, incapacity or incompetence of a member of the Commission and to make recommendations to the National Assembly on the removal of commissioners found guilty. Since its foundation, the IEC has presided over five general elections (1999, 2004, 2009, 2014 and 2019) and four municipal elections (2000, 2006, 2011, and 2016). The Commission's performance has improved significantly from election to election. For instance, a 2013/14 survey conducted by 
the Human Sciences Research Council (HSRC) found that the IEC was the third most trusted public institution. During the May 2014 elections, more than $90 \%$ of the voters were satisfied with the services of the IEC and held the view that the elections had been free and fair (Maaba 2015, p.115). Furthermore, the presence of international observers has decreased and domestic assessments of electoral process do not refer to indications of deliberate manipulation or rigging.

These developments may be seen as an acknowledgement of the maturity of South Africa's electoral democracy and the role that the IEC has played in this process. In particular, the IEC has fought to assert its independence in the face of the ANC's wavering commitment towards the independence of that entity. The following two examples illustrate this assertion: in August 1997 there was an impasse between government and the IEC. Government, especially the Department of Home Affairs (DoHA) and the Department of Finance (DoF), held the view that responsibility for administering elections lay with DoHA, and the IEC had only a supervisory role. From this perspective, the Commission was understood to be politically, administratively and financially subordinate to DoHA. DoHA went on to draft an amendment bill to the Electoral Commission Act, as the Commission asked for clarification on the reasons behind the government's interpretation of the legal framework. DoHA's amendment bill was approved by Cabinet and submitted to Parliament for discussion and approval. However, government retreated from the amendment bill amid protests from IEC. The Commission stressed that the moves by government were an attempt to undermine the independence of the Commission, and amounted to a return to the practices of the apartheid era, when government ran elections through the DoHa.

Relations between the IEC and DoHa reached a low point when government decided to cut down on the IEC's budget for the 1998/1999 financial year. The government proceeded to appoint 72500 public officials to assist with electoral matters in order to make up the shortfall (Ndletyana 2015a, p. 52). The chairperson of the Commission resigned in protest, citing, amongst others, the fact that the Commission had no control over civil servants - a situation that cast suspicions on their impartiality. Eventually, the Constitutional Court (ConCourt) resolved the deadlock. This was done indirectly in the course of a judgement for an appeal brought to the ConCourt by the NP. The judgement included comments that 'cast a dim light on the conduct of government suggesting that, were the Commission to take government to court on those matters, the court would find in the Commission's favour' (Ndletyana 2015a, p.52). The court's implicit warning to government re-affirmed the independence of the IEC, leading government to change its attitude towards the Commission. 
In recent years, questions have been raised regarding the ability of the IEC to run elections impartially. These emerged in the wake of a controversy surrounding the misconduct of a former commissioner which raised issues relating to the jurisdiction of the Electoral Court. Former Commissioner Pansy Tlakula had been found guilty of unethical behaviour by influencing the awarding of a contract to a business partner during her tenure as the Commission's CEO (Ndletyana 2015b, p.172). Opposition parties called for Tlakula's resignation, arguing that if the CEO could influence the award of a contract nothing could prevent her from benefitting the ruling party. Using their majority in parliament, ANC parliamentarians were reluctant to hold Tlakula to account, questioning the jurisdiction of the Electoral Court over the matter since Tlakula was not a commissioner when the incident occurred.

Opposition parties took the matter to the Electoral Court, which ruled for the removal of Tlakula from office. The court set a precedent by finding that commissioners are not only expected to act ethically during their time in office but are also held accountable for their behaviour prior to their appointment to the Commission. In this regard, an analyst remarked that: 'the Electoral Court has raised the moral standards to which commissioners are held. This will go a long way towards ensuring that the commission is staffed with individuals of unquestionable moral standing and will thus enhance the integrity of the IEC' (Ndletyana 2015a, p.186).

In the end, the IEC was able to prevail over the ANC's encroachments on its independence with the help of the courts, which are perceived to operate independently. These examples speak to the mutually reinforcing character of institutions, as an independent judiciary was able to re-affirm the independence of the EMB, its impact on the quality of electoral governance, and the overall quality of the political system.

\section{A HIGHLY POLITICISED EMB IN MOZAMBIQUE}

Following decades of fighting against Portuguese colonial rule, the Frente de Libertação de Moçambique (Frelimo) took up political power as the government at independence in 1975. Once in power, Frelimo set out to govern Mozambique as a one-party state based on Marxist-Leninist principles. Opposition to Frelimo found its most radical expression in an armed rebellion led by the Resistência Nacional Moçambicana (Renamo). This was an anti-communist insurgent group supported by Ian Smith's Rhodesia and later by apartheid South Africa within the context of the Cold War in southern Africa. Shifting regional and international political dynamics in the late 1980s opened the doors for the inception of diplomatic negotiations between the belligerents aimed at ending the armed conflict. These 
efforts culminated in the signing of a general peace agreement in Rome in October 1992.

Parallels have been drawn between the Angolan and Mozambican peace processes. Like the Bicesse Peace Accords in Angola, the Rome Peace Accords centered on military and political issues. On the military front, the agreements called on Frelimo and Renamo to observe a ceasefire, demobilise their armies and form a new unified national army. On the political front the settlement called for national multiparty elections as a channel to conclude Mozambique's transition from a one-party state to a multiparty democratic dispensation. However, there was massive international support and involvement in the implementation of the terms of the peace accord in order to prevent a repetition of the 'Angolan debacle' (Tvedten 1993, p. 108). This included the deployment of a large civilian and military contingent from the UN which had been charged with overseeing the transition process.

In preparation for the first multiparty elections, a new electoral law (Law 4/1993) was approved on 12 January 1994. This legislation made provisions for the establishment of institutions responsible for running Mozambique's elections. These were the Comissão Nacional das Eleições (National Commission for Elections or CNE) and the Secretariado Técnico de Administração Eleitoral (Technical Secretariat for Elections Administration or STAE), which was a subordinate agency answerable to the CNE. The former was designed to deal with political issues while the latter was expected to focus solely on the technical and administrative operations of the electoral process. The CNE had 20 members: ten members from the government, which was led by Frelimo; seven from Renamo and three from existing civilian parties created in the aftermath of the war. The STAE comprised 50 technicians: 25 technicians from the government led by Frelimo, 13 from Renamo and 12 from other political parties and the UN. The president of the CNE was to be appointed by the president of the Republic after a selection by the members of the Commission.

It should be noted that although the composition of the CNE and STAE was politically charged, in practice no party exercised dominance over the electoral agencies. This was for at least two reasons: firstly, selection to both entities was based on the principle of parity between Frelimo, Renamo and other political organisations; and secondly, the electoral law mandated all parties to observe consensus in decision-making.

In this context the elections were held on 27 October 1994. Haines and Wood (1995) report that 'despite allegations of irregularities, most notably of Zimbabwean nationals voting in the frontier regions and a large number of spoilt papers, the elections were generally accepted as free and fair' (p. 263). The electoral results confirmed a victory for Frelimo $(44.33 \%)$ and its presidential candidate 
Joaquim Chissano (53.3\%), against Renamo (37.78\%) and its leader, the late Afonso Dhlakama (33.7\%). A third party, the Democratic Union (DU) received 5.44\% of the votes. These results translated into 129 seats for Frelimo, 112 for Renamo and 9 for UD in the 250-seat Assembleia da República (parliament). Unlike the Angolan experience two years earlier, the international community and domestic political actors hailed Mozambique's founding elections as a success since all parties accepted the results. This success can be partly attributed to the role played by the electoral agencies as they ensured the credibility of the electoral process.

However, parity in the composition of Mozambique's electoral agencies and mandatory consensus in decision-making were subsequently abandoned. For instance, in preparation for the country's first local elections held in 1998, the Frelimo-dominated legislature approved a new electoral law linking political representation in the CNE to a party's share of seats in parliament. Furthermore, the new electoral legislation provided for decision-making by a simple majority. In this regard, an analyst explains that 'as the dominant party, FRELIMO was therefore able to pass a law that gave it more representatives on the election commission while establishing a decision-making procedure that ensured the party's dominance in electoral management' (Mawson 2010a, p. 11). Accordingly, the new electoral management body comprised nine members: the president of the commission, appointed by the president of the Republic; one member appointed by the Council of Ministers; and seven members appointed by Frelimo and Renamo in accordance with their strength in parliament. ${ }^{7}$

These developments inaugurated a pattern that was to play out in all subsequent electoral processes: reformulation of electoral rules, reorganisation of electoral management, and Frelimo's victory followed by Renamo's contestation of the results. For instance, following the disputes around the administration of the 1998 local elections, parliament approved new legislation to set up a new electoral commission to run the country's second presidential and legislative elections, which were scheduled for 1999. The new electoral law addressed Renamo's demands for increased political representation at both the CNE and STAE. Consequently, the new CNE was set up in March 1999. It comprised seventeen members appointed as follows: eight members appointed by Frelimo, six by Renamo, one by the Democratic Union and two members by government. Frelimo and its presidential candidate, Joaquim Chissano, emerged as the winners with $48.54 \%$ and $52.29 \%$ of the votes respectively. Renamo, which formed a coalition to run in the elections, accused the CNE of bias, demanding a recount of the votes. Although the Supreme Court ruled against Renamo, accusations regarding the poor performance of the electoral agencies seem to find support

7 Renamo refused to take part in the elections as a sign of protest. 
in the Carter Center's assessment that the 1999 elections had not been free and fair (The Carter Center, 2000).

Reformulations of electoral legislation, including provisions for the composition of the electoral commission, were carried out in preparation for the 2004, 2009 and 2014 elections. In relation to the 2014 electoral process, Renamo and a group of 12 small opposition parties accused the STAE of 'deliberately disorganizing the voter registration and the counting process' (Rosário 2016, p. 199). There was also a controversy around article 85 of the electoral law. The article stated that:

in the case of a discrepancy between the number of ballot papers in the ballot boxes and the number of voters, if the number of ballot papers in the ballot box is not greater than the number of registered voters the vote will be considered valid ... in case of the number of ballot papers in the ballot box being higher than the number of registered voters, the vote will be considered null'.

(Rosário 2016, p. 199)

Opposition parties called for a review of the content of the article because it jeopardised the 'transparency of the electoral process'. However, the Frelimodominated legislature refused to change the formulation of the aforementioned article.

These grievances led opposition parties to withdraw from the electoral process. Renamo went as far as conducting armed attacks in the central parts of the country. The confrontations ended with an agreement providing for consensual electoral reform between Renamo and Frelimo. Subsequently, 'Frelimo agreed to a set of electoral reforms presented by Renamo and enforced by Law 9/2014' (Rosário 2016, p.200). Like the 1999 legislation, the new law provides for a CNE comprising 17 members. However, there are notable differences in the criteria for the selection of commissioners, with five being nominated by the Frelimo, four by Renamo, one by the Democratic Movement of Mozambique (MDM) and the remaining seven members being drawn from civil society organisations. In this regard, Mawson (2010b) notes that 'this decision represented little risk to FRELIMO, because most civic organizations had originated with the party and were only slowly gaining an independent foothold' (p. 11). ${ }^{8}$ Frelimo and its presidential candidate won the country's fifth multiparty presidential and

8 These events speak to the highly bipartisan character of the Mozambican political system where Renamo often achieves through the bullet what it fails to achieve through the ballot. In this context, the non-armed opposition parties play a peripheral role. However, in recent years, the Movimento Democrático de Moçambique (MDM), a Renamo breakaway party, is emerging as Mozambique's third strongest political force. 
legislative elections. The aftermath of the elections witnessed another peaceful transfer of power from Armando Gebuza, who had succeeded Joaquim Chissano, to his defence minister Filipe Nyuse.

\section{CONCLUSION}

Although there are many contextual variables affecting the course of democratisation, institutions play a crucial role in these processes as democratisation involves crafting institutions (Di Palma, 1990). In emerging democracies, the fate of transition and consolidation processes is often dependent on the character of electoral institutions, which tend to reflect the correlation of forces between the incumbent and opposition groups at the crucial moment of their genesis. Building on these insights, this study examined democratisation with a focus on electoral governance. More specifically, the study investigated the role of EMBs in accounting for the distinctive regime trajectories of the southern African states of Angola, South Africa and Mozambique.

The inception of democratisation processes in these countries was the result of political negotiations to end protracted armed conflicts in the early 1990s. Negotiations took place as a result of a military stalemate between the incumbent regime and opposition forces. The institutions of electoral governance that emerged from this correlation of forces between the belligerents were consensual and balanced, with neither the incumbent nor the opposition having effective control over the EMBs. As outlined in the analysis, the independent character of these electoral institutions was enshrined in the legal-institutional framework, the provisions for their composition, and the actual management of the electoral process. As a result, the founding elections in Angola, South Africa and Mozambique were declared to be free and fair, confirming the formal transition to multiparty democratic politics.

However, changes in the balance of power in the aftermath of the founding elections encouraged the winners to redesign the institutions of electoral governance. In cases where these attempts were successful, incumbents established self-serving EMBs affecting both the credibility of subsequent elections and the trajectory of the democratisation process. This helps to explain why post-war Angola has become an electoral authoritarian regime. As noted in the discussion, after their military subjugation of UNITA in 2002, the governing MPLA restructured the EMB, bringing it under the party's control. Since then the MPLA has won all subsequent elections with a two-thirds majority, cementing the party's status as the dominant force in Angolan politics.

In line with the analytical parameters adopted in this study, post-apartheid South Africa's position in the category of liberal democratic states can be 
understood in terms of the independent character of electoral management in the country. As outlined above, attempts by the ANC to subvert the independence of the EMB have failed mainly because the guiding principles for the establishment of the country's democratic institutions were negotiated during the transitional period, thus preventing any one party from redesigning institutions unilaterally. Consequently, the country has a set of independent institutions with effective systems of checks and balance in place.

Like the MPLA in Angola, Frelimo has also succeeded in redesigning the rules of the game in Mozambique. However, an armed Renamo often threatens a return to war in order to get political concessions from the ruling party. ${ }^{9}$ As a result, legislation for the establishment of new electoral institutions is negotiated in preparation for every electoral process since the country's founding elections. Despite these developments, Mozambique has held elections in a relatively better political environment than Angola (as noted by Freedom House 2018). In addition, the country experienced two successful presidential successions in 2005 and 2015 respectively, since the transition to formal democratic rule. Angola has experienced its first presidential succession in 2017 after 38 years of President dos Santos's rule. This, I believe, takes the similarities between Angola and Mozambique beyond mere semantics, justifying the latter's ambivalent position between electoral authoritarian and a liberal democratic regime.

\section{----- REFERENCES}

Cheeseman, N, Collord, M \& Reyntjens, F 2018, 'War and Democracy: the legacy of conflict in East Africa', Journal of Modern African Studies, vol. 56, no. 1, pp. 31-61.

Catt, H, Ellis, A, Maley, M, Wall, A \& Wolf, P 2014, ‘Electoral Management Design: Revised Edition', International IDEA, Stockholm.

Di Palma, G 1990, To Craft Democracies: An Essay on Democratic Transitions, University of California Press, Berkeley.

Freedom House 2018, Mozambique, https: / freedomhouse.org/ report / freedomworld-2018-table-country-scores.

Gazibo, M 2006, 'The Forging of Institutional Autonomy: A Comparative Study of Electoral Management Commissions in Africa', Canadian Journal of Political Science. vol. 39, no. 3, pp. 611-633.

9 As recently as 6 August 2019, roughly three months before Mozambique's next elections scheduled for 15 October 2019, President Filipe Nyusi and Renamo's leader Ossufo Momade signed a new Peace and National Reconciliation Agreement. 
Gilliomee, H 1995, 'Democratization in South Africa', Political Science Quarterly, vol. 110, no. 1, pp. 83-104.

Hall, PA, \& Taylor, RC 1996, 'Political Science and the Three New Institutionalisms', Political Studies, vol. 44, pp. 936-957.

Hartlyn, J McCoy, J \& Mustillo, T 2008, 'Electoral Governance Matters: Explaining the Quality of Elections in Contemporary Latin America', Comparative Political Studies, vol. 41, no.1, pp. 73-98.

Haines, R \& Wood, G 1995, 'The 1994 election and Mozambique's democratic transition', Democratization, vol. 2, no. 3, pp. 362-376.

Huntington, S 1991, The Third Wave: Democratization in the Late Twentieth Century, University of Oklahoma Press, Oklahoma.

Lecours, A 2005, 'New Institutionalism: Issues and Questions', In Lecours, A. (ed), New Institutionalism: Theory and Practice, University of Toronto Press, Toronto.

Lowndes, V \& Roberts, M 2013, Why Institutions Matter: The New Institutionalism in Political Science, Palgrave Macmillan, New York.

Lopez-Pintor, R 2000, Electoral Management Bodies as Institutions of Governance, United Nations Development Programme, New York.

Maaba, BB 2015, 'Free at Last', In M Ndletyana (ed), Institutionalising Democracy: The Story of the Electoral Commission of South Africa, 1993-2014, pp.102-121.

Matlosa, K 2017, 'The State of Democratisation in Southern Africa: Blocked Transitions, Reversals, Stagnation, Progress and Prospects', Politikon, vol. 44, no. 1, pp. 5-26.

Mawson, A 2010a, 'Organizing the First Post-Apartheid Election: South Africa, 1994', Innovations for Successful Societies, Princeton University. Available at $<$ http:/ / www.princeton.edu/successfulsocieties> [20 April 2019].

Mawson, A 2010b, 'Compromise and Trust-Building After Civil War: Elections Administration in Mozambique, 1994', Innovations for Successful Societies, Princeton University. Available at: <http://www.princeton.edu/ successfulsocieties> [20 April 2019].

Mozaffar, S 2002, 'Patterns of electoral governance in Africa's emerging democracies', International Political Science Review, vol. 23, no.1, pp. 85-101.

Mozaffar, S \& Schedler A 2002, 'The comparative study of electoral governance: Introduction', International Political Science Review, vol. 23, no.1, pp. 5-27.

Ndletyana, M 2015a, 'The IEC and the 2014 Elections: A Mark of Institutional Maturity?', Journal of African Elections, vol.14, no.1, pp.171-187.

Ndletyana, M (ed) 2015b, 'Evolution of Electoral Governance in South Africa', In E Ndletyana, (ed), Institutionalising Democracy: The Story of the Electoral Commission of South Africa, 1993-2014, pp. 26-71.

Pastor, RA 1999, 'The role of electoral administration in democratic transitions: Implications for policy and research', Democratization, vol. 6, no. 4, pp. 1-27. 
Rosário, DM 2016, 'Mozambique', In OSISA, Election Management Bodies in Southern Africa: Comparative study of the electoral commissions' contribution to electoral processes, OSISA, Johannesburg.

Schedler, A 2002, 'The Menus of Manipulation', Journal of Democracy, vol. 13, no. 2, pp. 36-50.

Schedler, A 2015, The Politics of Uncertainty: Sustaining and Subverting Electoral Authoritarianism, Oxford University Press, Oxford.

Soares de Oliveira, R 2015, Magnificent and Beggar Land: Angola Since the Civil War, Oxford University Press, Oxford.

The Carter Center 2000, Observing the 1999 Elections in Mozambique, Available at <https: / / www.cartercenter.org/documents/280.pdf> [20 April 2019].

Troco, AA 2019, 'Electoral Politics and Political Transition in Post-war Angola: Progress, Problems and Prospects', Journal of African Elections, vol. 18, no. 1, pp. 23-44.

Tvedten, I 1993, 'The Angolan Debacle', Journal of Democracy, vol. 4, no. 2, pp. 108-118. 